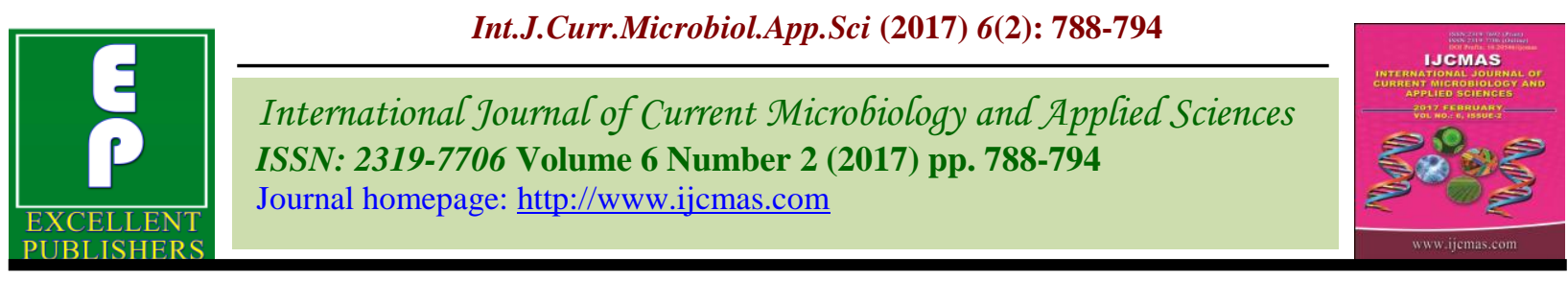

Original Research Article http://dx.doi.org/10.20546/ijcmas.2017.602.087

\title{
Identification of Most Important Weeks on Minimum Temperature for Wheat Crop
}

\author{
K.K. Pandey ${ }^{1}$, C.K. Chandrakar ${ }^{1}$, S.K. Singh ${ }^{2}$, D. Maurya ${ }^{3}$ and G. Gupta ${ }^{4}$ \\ ${ }^{1}$ SK College of Agriculture and Research Station, Kawardha, Kabridham (C.G.) - 491995, India \\ ${ }^{2}$ Bhoramdev College of Agriculture, Kawardha, Kabridham (C.G.) - 491995, India \\ ${ }^{3}$ Research Scholar, Indian Institute of technology, Roorkee (Uttarakhand) - 247667, India \\ ${ }^{4}$ Baba Farid Institute of Technology, Dehradoon (Uttarakhand), India \\ *Corresponding author
}

\begin{tabular}{|c|c|}
\hline & A B S T R A C T \\
\hline Keywords & \multirow{4}{*}{ 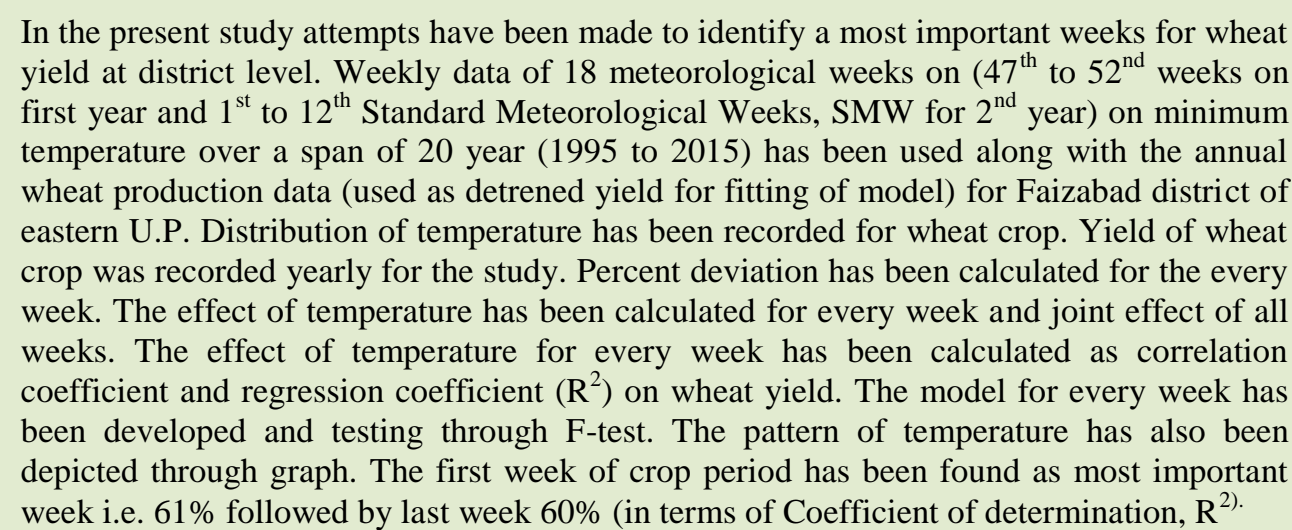 } \\
\hline $\begin{array}{l}\text { Percent deviation, } \\
\text { Wheat crop, } \\
\text { Temperature and } \\
\text { coefficient of } \\
\text { determination (R2). }\end{array}$ & \\
\hline Article Info & \\
\hline $\begin{array}{l}\text { Accepted: } \\
\text { 18 January } 2017 \\
\text { Available Online: } \\
10 \text { February } 2017\end{array}$ & \\
\hline
\end{tabular}

\section{Introduction}

Agriculture in the entire world mostly depends on the persisting weather conditions. The alternation in global warming has dramatically affected agriculture and its productivity. The increase in temperature has significantly led to change in the agricultural zones and shift in the growing seasons. Among these changes, the change in rainfall pattern is the serious threat to the agriculture, which in turn affects the country's economy and food security. The delayed or inadequate monsoon also cause influence on the sale of agriculture inputs such as fertilizers, agrochemicals etc. Some of the areas in India receive more rainfall than normal while some receive below the normal. The various studies showed the overall loss in the crop production in the country in the last few years was due to the anticipated rise in the temperature. Kumar et al., (2016) has suggested model which require small number of parameters to be estimated while taking care of distribution pattern of weather over the crop season and Crop yield forecasting of paddy and sugarcane through modified Hendrick and Scholl technique for south Gujarat. 
Wheat is one of the most important food grains for cultivation in Rabi season and consumption as well in eastern Uttar Pradesh. In eastern U.P. region of India wheat is generally sown from second week of November.

The meteorological statistics and yield data from the phonological period in which weather elements illustrate significant correlation with crop yield by using multiple linear regressions. As climatic patterns change, so also the spatial distribution of agro ecological zones, habitats, dissemination of plant diseases and pest and ocean circulation patterns changes that cause serious impact on agriculture and food production. Models based on weather parameters can provide reliable forecast of crop yield in advance of harvest (Agrawal and Mehta, 2007). Abnormal changes in climate and resulting increase in frequency and intensity of drought have long-term implications for the viability of these ecosystems. Some forecasting equations have also been developed so for forecasting of rice yield, for estimation of sugarcane yield and for wheat yield (Agarwal et al, 2012) have been proved their importance.

The Pre-harvest forecast of crop yield is very useful for Government and Planners in taking various policy decisions relating to procurement, storage, distribution, marketing, price, export-import, etc. A lot of work has been done by different scientist in this direction in different part of the country, but no work has been done by someone in this region in this direction. First time the effect and pattern of minimum temperature consider for study for this region.

\section{Materials and Methods}

The study has been conducted for Faizabad district of Eastern Uttar Pradesh, which is situated between $26^{\circ} 47^{\circ} \mathrm{N}$ latitude and $82^{\circ}$ 12 ' E longitudes. It lies in the Eastern Plain Zone of Uttar Pradesh. The annual rainfall of study area about $1002 \mathrm{~mm}$ and is liberally sourced by the Sarju (Ghaghra) river and its tributaries. Soils are deep alluvial, medium to fine textured but are easily ploughable. The favorable climate, soil and the availability of ample irrigation facilities make rice and wheat is suitable crops for that area. Wheat crop is generally cultivated during the Rabi season because during this period crop receives a better temperature along with other weather variables.

Time series data on yield for wheat crop pertaining to Faizabad district of Uttar Pradesh for 20 years (1995- 2015) have been procured from Directorate of Agricultural Statistics and Crop Insurance, Government of Uttar Pradesh.

Weekly weather (minimum temperature) data for similar period of Faizabad district of Uttar Pradesh during the crop growth period have been obtained from the department of Agrometeorology, N.D. University of Agriculture and Technology Kumarganj, Faizabad. The data on minimum temperature has been collected for 18 weeks $\left(47^{\text {th }}\right.$ week to $52^{\text {nd }}$ from $1^{\text {st }}$ year and $1^{\text {st }}$ week to $12^{\text {th }}$ week from $2^{\text {nd }}$ year) (Table 2 ).

\section{Effect of minimum temperature}

In order to study the effect of individual weather variable, two new variables from each weather variable are generated as following Pandey et al., (2016):

Let $\mathrm{X}_{1 \mathrm{w}}$ be the value of $1^{\mathrm{st}}$ weather variable at $\mathrm{w}^{\text {th }}$ weeks $(\mathrm{w}=1,2, \ldots .18)$ in this study $\mathrm{n}$ is 18.

$$
Z_{10}=\sum_{w=1}^{18} X_{1 w} / 18
$$


Let $r_{1 \mathrm{w}}$ be the simple correlation coefficient between weather variable $\mathrm{X}_{\mathrm{i}}$ at $\mathrm{W}$-th week and detrended crop yield over a period of $\mathrm{K}$ years and $\mathrm{r}_{1 \mathrm{w}} \mathrm{X}_{1 \mathrm{w}}$ is the product moment. The generated weighted variables

$Z_{11}=\sum_{w=1}^{18} r_{1 w} X_{1 w} / \sum_{w=1}^{18} r_{1 w}$

for each year. The following model is then fitted to study the joint effect of all 18 weeks on minimum temperature

$Y=a_{0}+a_{1} z_{10}+a_{2} z_{11}+c T+\varepsilon$
Where $\mathrm{Y}$ is detrended yield; $\mathrm{T}$ is variable expressing time effect, $\mathrm{a}_{0}, \mathrm{a}_{1}, \mathrm{a}_{2}$ and $\mathrm{c}$ are parameters of the model to be evaluated for the effect of variables and $\varepsilon$ is error term supposed to follow normal distribution with mean zero and variance $\sigma^{2}$.

\section{Percent Deviation}

This measures the deviation (in percentage) of forecast from the actual yield data. The formula for calculating the percent deviation of forecast is given below

\section{Percent deviation $=\frac{(\text { Actual yield- Forecasted yield })}{(\text { Actual yield })} \times 100$}

\section{Pattern of Minimum temperature}

The pattern of weather variables have been worked out in crop period and depicted through graphs.

\section{Results and Discussion}

\section{Effect of minimum temperature}

The multiple regression equation obtained is

$Y=2560.68+22.96 Z_{10}-32.97 Z_{11}+18.01 T$

The results from table 1 indicates that weighted weather variable $\left(\mathrm{Z}_{11}\right)$ found positive and significant at $1 \%$ level, time trend $\mathrm{T}$ found positive and significant at $1 \%$ level and unweighted weather variable was significant at $10 \%$ level. The value of $\mathrm{R}^{2}$ was $80.60 \%$ which is significant at $1 \%$ level of significance. Nain et al., (2004) also reported that the differences between observed and predicted wheat yield were, on an average, $4.72 \%$ by using weather variables for IndoGangetic plains. Likewise, yield of groundnut was significantly correlated with growing season rainfall in southern India Gadgil et al., (2002).

\section{Pattern and Role of weekly Minimum Temperature}

First Standard Meteorological Week (47th) of wheat sown crop period plays most important role in terms of multiple $\mathrm{R}^{2}$ i.e. $62 \%$, followed by last week (12th) with $60 \% \mathrm{R}^{2}$. Correlation Coefficient between yield and average weekly temperature during the crop period found negative and maximum in first week followed by last week i.e. -.62 and -0.60 . In terms of significance only first and last week found significant at $1 \%$ level. After that 6th week (i.e. flowering stage) plays an important role. The $\mathrm{R}^{2}$ value for the $6^{\text {th }}$ week is $42 \%$ which is significant at $10 \%$ level. The correlation coefficient between yield and $6^{\text {th }}$ week of minimum temperature is 0.42 .

Lal et. al. (1999) also observed that maximum temperature, minimum temperature and moisture stress were crucial weather variables affecting soybean yield. 
Table.1 Effect of minimum temperature

\begin{tabular}{|c|c|c|c|c|c|}
\hline \multirow{2}{*}{ Variable } & \multirow{2}{*}{$\begin{array}{c}\text { Regression coefficient } \\
\text { (standard error) }\end{array}$} & \multirow{2}{*}{$\mathrm{P}$ value } & \multirow{2}{*}{$\mathrm{R}^{2}$} & \multicolumn{2}{|c|}{$95 \%$ confidence interval } \\
\cline { 6 - 6 } & & & & Lower & Upper \\
\hline Intercept & 2560.68 & & 1220.91 & 3900.46 \\
\hline $\mathrm{Z} 10$ & $22.96(72.29)$ & 0.75 & \multirow{2}{*}{$80.60 *$} & -130.29 & 176.22 \\
\hline $\mathrm{Z} 11$ & $-32.97(14.75)$ & 0.04 & & -64.23 & -1.71 \\
\hline $\mathrm{T}$ & $18.01(7.57)$ & 0.03 & & 1.96 & 34.05 \\
\hline
\end{tabular}

** $\mathrm{P}<0.05, * \mathrm{P}<0.01,{ }^{+} \mathrm{P}<0.1$

Table.2 Role of different weeks in crop yield forecasting

\begin{tabular}{|c|c|c|c|c|c|}
\hline S.No & $\begin{array}{c}\text { SMW(Standard } \\
\text { Meteorological } \\
\text { Weeks }\end{array}$ & $\begin{array}{c}\text { Correlation } \\
\text { Coefficient }\end{array}$ & $\mathrm{R}$ & $\begin{array}{c}\text { Significance } \\
\text { of the } \\
\text { model }\end{array}$ & $\begin{array}{c}\text { Predicted } \\
\text { Yield at } \mathrm{n}^{\text {th }} \\
\text { week }\end{array}$ \\
\hline 1. & 47 & -0.62 & & 0.001 & 2686.31 \\
\hline 2. & 48 & -0.31 & & 0.18 & 2618.58 \\
\hline 3. & 49 & 0.04 & & 0.86 & 2611.42 \\
\hline 4. & 50 & -0.10 & & 0.69 & 2616.01 \\
\hline 5. & 51 & -0.28 & & 0.23 & 2563.44 \\
\hline 6. & 52 & 0.09 & & 0.70 & 2613.60 \\
\hline 7. & 1 & -0.08 & & 0.74 & 2615.70 \\
\hline 8. & 2 & -0.02 & & 0.92 & 2616.12 \\
\hline 9. & 3 & -0.16 & & 0.49 & 2593.90 \\
\hline 10. & 4 & -0.14 & & 0.56 & 2567.52 \\
\hline 11. & 5 & -0.02 & & 0.94 & 2610.06 \\
\hline 12. & 6 & 0.42 & & 0.06 & 2670.77 \\
\hline 13. & 7 & -0.07 & & 0.78 & 2620.89 \\
\hline 14. & 8 & 0.10 & & 0.68 & 2609.12 \\
\hline 15. & 9 & 0.36 & & 0.12 & 2696.28 \\
\hline 16. & 10 & 0.15 & & 0.53 & 2593.26 \\
\hline 17. & 11 & -0.26 & & 0.28 & 2692.15 \\
\hline 18. & 12 & -0.60 & & 0.005 & 2593.99 \\
\hline
\end{tabular}

Table.3 Validation of model

\begin{tabular}{|c|c|c|c|}
\hline years & Actual yield & Predicted yield & Percent Deviation \\
\hline $\mathbf{1 9}$ & 2976 & 2989.688 & -0.45994 \\
\hline $\mathbf{2 0}$ & 2896 & 2802.799 & 3.218272 \\
\hline
\end{tabular}


Int.J.Curr.Microbiol.App.Sci (2017) 6(2): 788-794

Table.4 Percent deviation from predicted value

\begin{tabular}{|c|c|c|c|}
\hline S.No. & Observed Value & $\begin{array}{c}\text { Predicted Value of nth } \\
\text { week }\end{array}$ & Percent Deviation \\
\hline 1 & 2530 & 2686.31 & -6.17826 \\
\hline 2 & 2502 & 2618.58 & -4.65947 \\
\hline 3 & 2676 & 2611.42 & 2.413303 \\
\hline 4 & 2397 & 2616.01 & -9.13684 \\
\hline 5 & 2230 & 2563.44 & -14.9525 \\
\hline 6 & 2626 & 2613.60 & 0.472201 \\
\hline 7 & 2357 & 2615.70 & -10.9758 \\
\hline 8 & 2392 & 2616.12 & -9.36957 \\
\hline 9 & 2179 & 2593.90 & -19.0408 \\
\hline 10 & 2637 & 2567.52 & 2.634812 \\
\hline 11 & 2377 & 2610.06 & -9.8048 \\
\hline 12 & 2607 & 2670.77 & -2.44611 \\
\hline 13 & 2683 & 2620.89 & 2.314946 \\
\hline 14 & 2758 & 2609.12 & 5.398115 \\
\hline 15 & 2819 & 2696.28 & 4.353317 \\
\hline 16 & 2790 & 2593.26 & 7.051613 \\
\hline 17 & 2810 & 2692.15 & 4.19395 \\
\hline 18 & 3013 & 2593.99 & 13.90674 \\
\hline
\end{tabular}

Fig.1 Predicted value at nth week

Predicted Yield at nth week

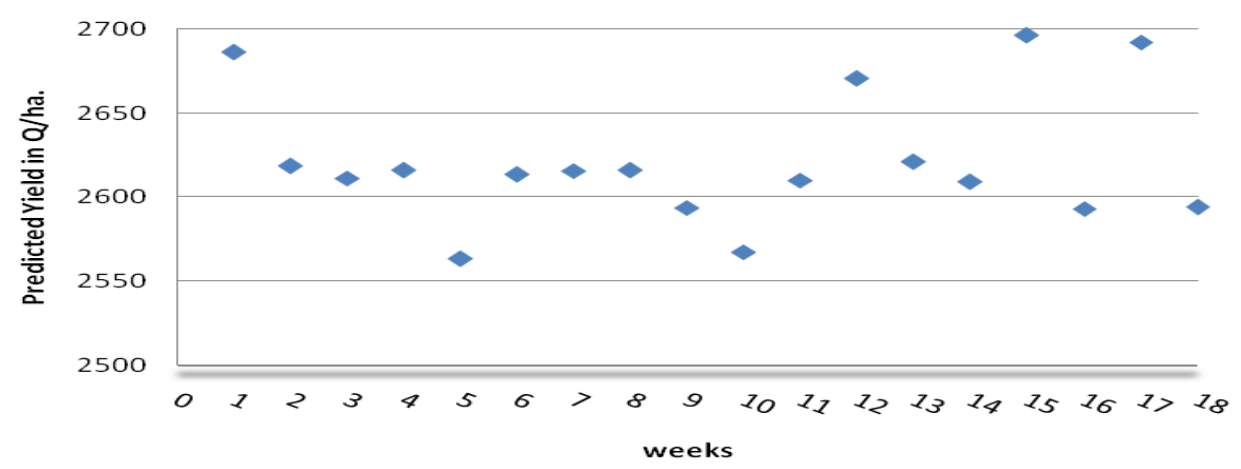


Fig.2 Trend of Minimum temperature over the Crop period

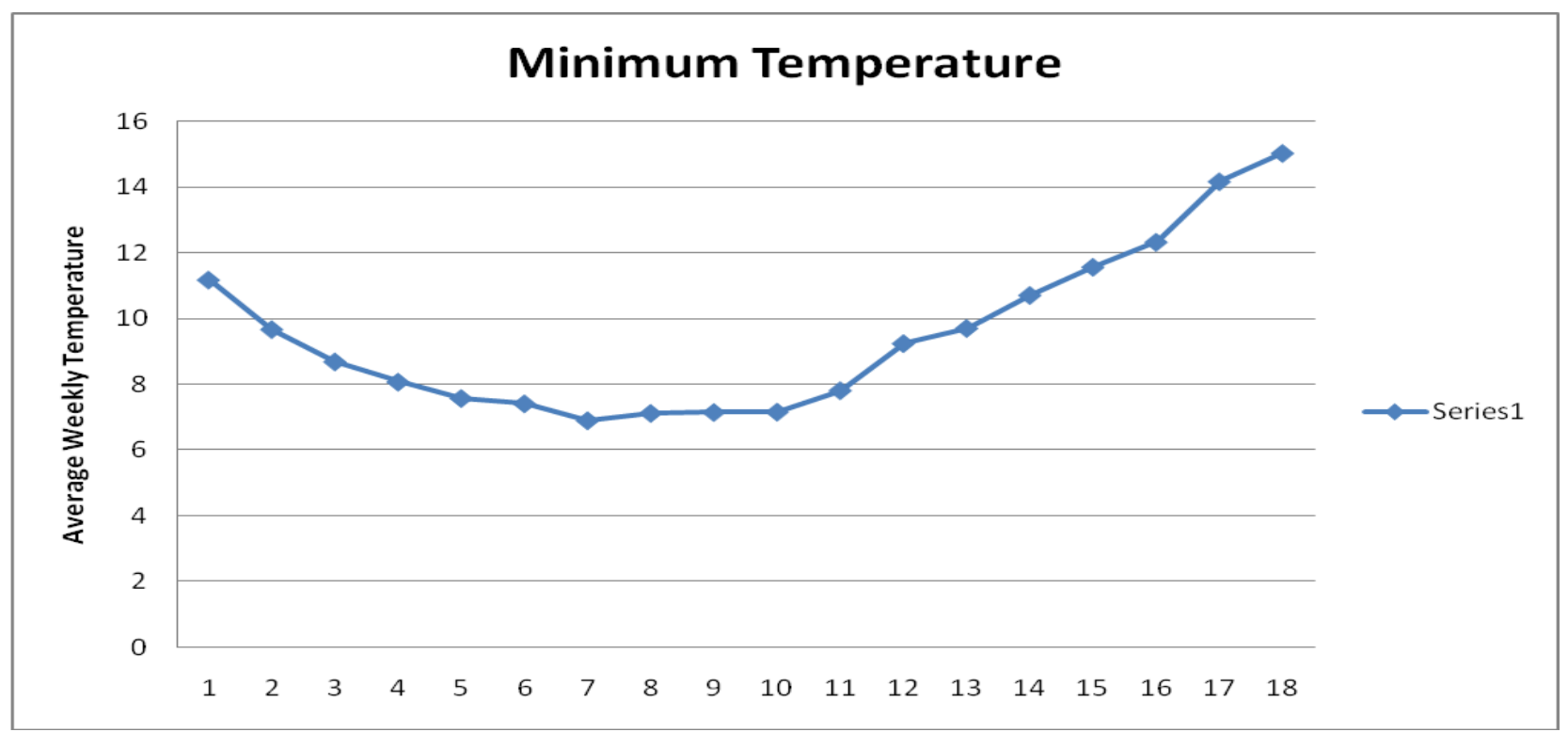

A combination of temperature and radiation was a better predictor of wheat grain yield Temperature, rainfall and relative humidity were found significantly correlated with sugarcane yield Srivastava et al.,(2007).

Our results are in line with Kumar et.al. (2014) multiple regression models were developed for yield forecasting of paddy, sugarcane and wheat for two districts of Gujarat (Navsari and Bharuch) on the basis of generated weather variables. Significant weather variables are obtained on the basis of highest $\mathrm{R}^{2}$ and significant $\mathrm{P}$-value Pandey et.al. (2014). Similar study done for Forecasting Model developed on weather parameters for faizabad district of Eastern U.P Pandey et al., (2016).

Almost similar results, as observed in this study, have also been reported by Kandiannan et al., (2002) for Coimbatore in Tamil Nadu, where temperature, rainfall and radiation entered significantly in a stepwise prediction equation of rice yield. In Andhra Pradesh also, rainfall and temperature have been reported to affect rice yield significantly (Barnwal and Kotani, 2010).
In conclusion, the study revealed that the wheat crop requires balanced weather parameters during all growth phase. Early growth phase require decreasing temperature, second stage requires constant temperature. However, at the maturity stage increasing temperature plays very important role. According to predicted model $\mathrm{R}^{2}$ is $81 \%$ effect on wheat yield. Percent deviation of predicted model has been very less i.e. -0.46 for I year and 3.22 for II year. Weekly predicted yield data have been calculated. It seems from the graph that technological development of minimum temperature is mixed up. However graph shows the proper pattern. This is the study of effect of change of yield due to variation of minimum temperature during wheat crop season (Table 3 and 4).

\section{References}

Agrawal R. and Kumar A. (2012). "Used Discriminant Function Analysis For Forecasting Crop Yield". Mausam, 63(3): 455-458.

Agrawal R. and Mehta S.C. (2007). "Weather Based Forecasting of Crop Yields, Pests 
and Diseases - IASRI Models". J. Ind. Soc. Agril. Stati. 61(2): 255-263.

Barnwal P. and Kotani K. (2010). Impact of Variation in Climatic Factors on Crop Yield: A Case of Rice Crop In Andhra Pradesh, India. Economics \& Management Series. 17. International University of Japan.741.

Gadgil S., Rao P.R.S. and Rao K.N. (2002). "Use of Climate Information For FarmLevel Decision Making: Rainfed Groundnut In Southern India". Agricultural Systems. 74: 431-457.

Kandiannan K., Karthikeyan R., Krishnan R., Kailasam C. and Balasubramanian T.N. (2002). Crop-Weather Model for Prediction of Rice (Oryza sativa L.) Yield Using an Empirical-Statistical Technique. Journal of Agronomy and Crop Science. 188 (1): 59-62.

Kumar N., Pisal R. R., Shukla S. P. and Pandey K. K. (2014). Crop yield forecasting of paddy, sugarcane and wheat through linear regression technique for south Gujarat. Mausam, 65 (3): 361-364.

Kumar N, Pisal R. R., Shukla S. P. and Pandey K. K (2016). Crop yield forecasting of paddy and sugarcane through modified Hendrick and Scholl technique for south Gujarat, Mausam, 67, 2:405-410.

Lal M., Singh K.K., Srinivasan G., Rathore
L.S, Naidu D. and Tripathi C.N., (1999). "Growth and yield responses of soybean in Madhya Pradesh, India to climate variability and change". Agricultural and Forest Meteorology. 93: 53-70.

Nain A.S., Dadhwal V.K. and Singh T.P., (2004). "Use of CERES-Wheat Model For Wheat Yield Forecast In Central Indo-Gangetic Plains of India". Journal of Agricultural Sciences, 142 (1): 59-70.

Pandey KK, Maurya D, Gupta G and Mishra SV (2016). Yield Forecasting Models based on Weather Parameters for Eastern U.P. Vegetos, 29(1):1-3.

Pandey KK,. Rai VN. Sisodia BVS, Pandey R and Pandey V.(2016). Development of Forecasting Model on Weather Parameters for Eastern U.P. Research in Environment and Life Sciences (Accepted).

Pandey K. K., Rai, V. N. and Sisodia, B. V. S. (2014). Weather Variables Based Rice Yield Forecasting Models for Faizabad District of Eastern U.P. Int. J. Agricult. Stat. Sci., 10 (2).

Srivastava A. K., Bajpai P.K., Yadav R.L and Hasan S.S. (2007). "Weather Based Sugarcane Yield Prediction Model for the State of Uttar Pradesh". Journal of Indian Society of Agricultural Statistics, 61(3): 313-327.

\section{How to cite this article:}

Pandey, K.K., C.K. Chandrakar, S.K. Singh, D. Maurya and Gupta, G. 2017. Identification of Most Important Weeks on Minimum Temperature for Wheat Crop. Int.J.Curr.Microbiol.App.Sci. 6(2): 788-794. doi: http://dx.doi.org/10.20546/ijcmas.2017.602.087 